\title{
ON THE GEOCHEMISTRY OF AMPHIBOLITE ENCLAVES IN THE PAN-AFRICAN GNEISSES OF WADI FEIRAN, SW SINAI, EGYPT, AND THEIR RELATION TO ARC MAGMATISM
}

\author{
Nahla A. Shallaly \\ shallalynahla@yahoo.de \\ Geology Department. Faculty of Science, Cairo University
}

\begin{abstract}
Geochemistry of amphibolite enclaves from the Pan-African Wadi Feiran area, SW Sinai, is presented with the aim to assess the petrogenetic characteristics of their protliths. These enclaves are concordantly enclosed in biotite, hornblende and quartzofeldspathic gneisses and schists, that overlie partially migmatized granitic gneisses. They occur as variably sized, massive to highly foliated and often strongly stretched, lenses and boudins. The studied enclaves are of magmatic origin with precursors ranging from calc-alkaline andesites to tholeiitic basalts. Rare enclaves of high-Mg appinitic monzogabbro and monzodiorite are recorded in the biotite gneisses, indicating a primary magma that was generated along a subduction zone. The geochemical characters of the studied enclaves indicate that during the Pan-African, the Wadi Feiran area constituted a back-arc continental lithosphere environment that witnessed plumesubduction interaction.
\end{abstract}

Keywords: Amphibolite enclaves, appinites, geochemistry, back-arc setting, Pan-African, Sinai, Egypt.

\section{INTRODUCTION}

Amphibolite enclaves of amphibolite to granulite facies occurring in metamorphosed gneisses are common in many belts worldwide, particularly those affected by high-pressure metamorphism (e.g. Pin and Veilzeuf, 1983; Chopin, 2003; Saha et al., 2008). Such enclaves are also described from different units in the Arabian Nubian Shield (ANS), which is part of the East African Orogen formed in the late Proterozoic (Neumayr et al., 1996; Maboko, 2000; Liégeois and Stern, 2010). They are of different composition and sizes and either of the same metamorphic grade as that of the host rock or not.

In Egypt, amphibolite enclaves are recorded in all the Pan-African rock units mainly the gneisses, ophiolitic mélanges, synorogenic granitoids and metavolcano-sedimentary associations in the Eastern Desert (e.g. El-Gaby and Habib, 1980; Takla et al., 1992; Surour, 1995) and south Sinai (e.g El- Gaby and Ahmed, 1980; El-Tokhi, 1990; Abu Anbar and Abd El-Wahed, 2004; Zayed, 2006; Shallaly, 2007). They have different precursors ranging from sedimentary, in the form of para-gneisses, to mafic-ultramafic igneous rocks (Akaad and Noweir, 1980; Basta et al., 1981). South Sinai comprises three metamorphic complexes of volcano- sedimentary origin: Sa'al (1003-930Ma), Feiran-Solaf (870 to 740Ma) and Kid (640-620Ma), as reported by Eyal et al. (2014). The Feiran-Solaf belt, which occupies SW Sinai, is one of the largest gneiss and migmatite belts of the Arabian-Nubian Shield (ANS). These infrastructural belts are structurally below arc assemblages or ophiolitic rocks (Hamimi et al., 2019) and have a very wide range of ages (614-1700Ma, as reported in Hassan and Hashad, 1990). The oldest unit (1839-2399Ma) is exposed along the southwest Western Desert, is of Pre-Pan-African age and constitutes the northern extension of the African craton (Schandelmeier et al., 1988). Many authors considered the Feiran-Solaf belt to be of Pre-Pan-African age and to have been incorporated in the Pan-African tectonic event (e.g. El-Gaby et al., 1990). However, a PanAfrican age of 623Ma was assigned it by Stern and Manton (1987) and 870-740Ma by Eyal et al. (2014). The belt hosts variably sized amphibolite enclaves in the form of concordant lenses and blocks along sharp contacts with the enclosing gneisses. This observation led many workers to assume that these enclaves are of magmatic origin. Predominantly in Wadi Solaf (Abu Alam, 2010) and rarely in Wadi Feiran (Zayed, 2006), these amphibolites are associated with calc-silicate enclaves of sedimentary origin and of the same metamorphic grade as the enclosing gneisses and schists. Apart from the calc-silicate enclaves, the amphibolite enclaves of Wadi 
Shallaly, N. A.

Feiran were identified as para-amphibolites (Akaad et al., 1967); nevertheless, El-Gaby and Ahmed (1980) interpreted amphibolite enclaves from Wadi Nefuz as a mixture of para-amphibolites and orthoamphibolites.

Although many of the ortho-amphibolite enclaves from Wadi Feiran were identified, their geochemistry and relation to one another and to metavolcanics from southern Sinai were not addressed. This research focuses on the tectono-magmatic signature of amphibolite enclaves from the Wadi Feiran area, in terms of the evolution of the Pan-African crust in the ANS.

\section{GEOLOGIC SETUP}

The Feiran-Solaf belt constitutes two major NNW-SSE double plunging anticlines that are separated by a synclinal trough and a high angle $\mathrm{N} 30^{\circ} \mathrm{W}$ thrust fault (e.g. Ahmed, 1970; El-Tokhy, 1990; Kabesh, 1993; Hashad et al., 2001). The Late Proterozoic rocks along this belt were classified into five stratigraphic formations (Ahmed, 1970; El-Gaby and Ahmed, 1980): the semi-pelitic Nidia El Samra overlain by the calc-pelitic Aleiyat Formation occupying the western Feiran anticline; the eastern Solaf anticline, occupied by the pelitic to calc-pelitic El Khalil Formation and the arenaceous Tarr Formation, are overthrust by the calc-pelitic El Shiekh Formation from the East. These rocks are believed to be an old volcanosedimentary succession of arenaceous, pelitic and calcareous composition with minor basic volcanic intercalations that were deposited in a bathyal to inner neritic environment on a continental slope (Belasy, 1991), and later metamorphosed to a group of biotite and hornblende-biotite gneisses, quartzofeldspathic gneisses and schists, calc-silicate rocks and migmatites that are intruded by granitic gneisses (610-643Ma, Bielski, 1982;Stern and Manton, 1987; El-Tokhi, 1990; Zayed, 2006). Combined processes of metamorphic differentiation, partial melting and metasomatism were suggested for the development of the recorded stromatic, agmatic and ophthalmitic migmatites (Kabesh, 1993). These rocks are intruded by large amounts of diorite, granite and syenite and later by mafic - felsic dyke swarms and pegmatites (e.g. El-Gaby and Ahmed, 1980; Hassan and Hashad, 1990; Zayed, 2006). The area was affected by polyphase ductile/brittle deformation synchronous with polyphase metamorphism and pervasive migmatization (e.g. Kabesh, 1993; El Shafei and Kusky, 2003; Sultan, 2003). In Wadi Feiran and its tributaries Wadi Qusier, Wadi Amayiem and Wadi Nefuz (Fig.1), Zayed (2006) recorded the presence of three deformational phases, D1-D3, each generating its own characteristic folds and penetrative planar as well as linear fabrics. The highest metamorphic grade, reached during D1, was of upper amphibolite facies. The author recorded enclaves of different composition in the form of rare migmatites with diffuse contacts against the enclosing granitic gneisses; as well as hornblende gneiss, appinitic meladiorite and minor calc-silicate enclaves in the overlying schists and gneisses.

The studied amphibolite enclaves along Wadi Qusier, Wadi Amayiem, and Wadi Nefuz range from huge mappable elongated masses (Fig. 2a and b) to small, tens of cm-long lenses and boudins (Fig.2c) in hornblende-biotite gneisses. Variably-sized, much thinner enclaves as well as bands are also recorded in quartzofeldspathic schists (Fig.2d). They are easily detectable through their dark green to black colour and sharp contacts with their greyish to brownish host para-gneisses. They range from fine- to mediumgrained, and are foliated and nematoblastic to massive. Their foliation is concordant to, and wrapped around by, the main foliation of the enclosing gneisses.

\section{ANALYTICAL METHODS}

Whole rock chemistry of 14 samples from Wadi Feiran and its tributaries was carried out. A SRS303AS X-ray fluorescence spectrometer (XRF) equipped with a Rh tube, at the Geozentrum Nordbeyern, University of Erlangen, Germany, was used. Analyses of the samples are presented (Table 1). Precision for most elements was better than $0.8 \%$ and accuracy better than $1 \%$ of the measured values. International standards of appropriate compositions were chosen and simultaneously subjected to the same procedure of disc preparation, to test the precision of the analytical results. Duplicate discs were prepared for each standard. The selected standards were: basalt (JB2 and JB3) and andesite (JA2) and gabbro (JGB1). 
Fig. 1: Location and geologic map of the western part of Wadi Feiran, SW Sinai, showing the distribution of the huge mappable amphibolite enclaves (modified after Zayed, 2006)

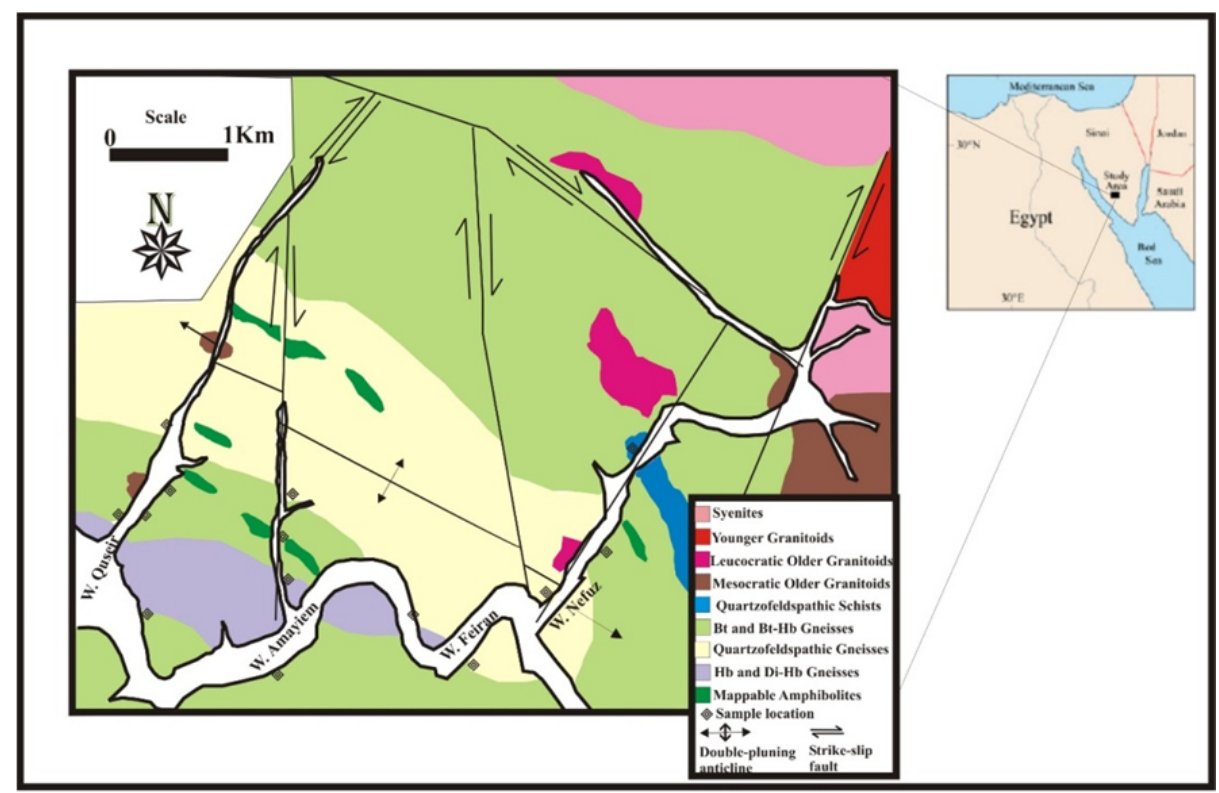

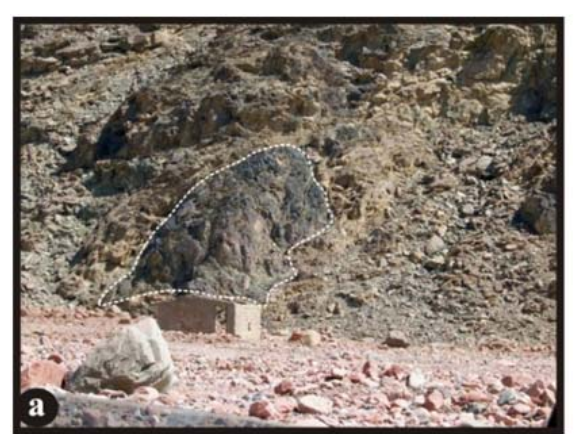

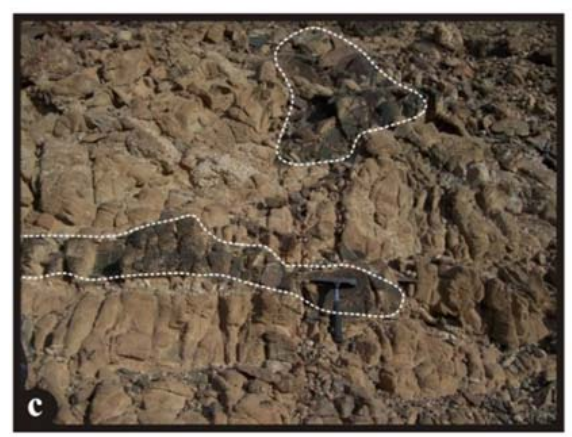

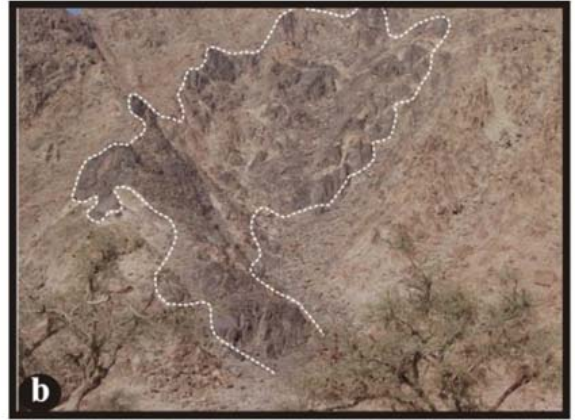

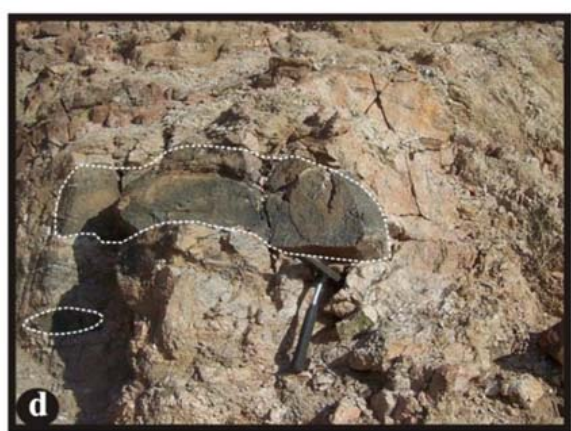

Fig. 2: a. A huge foliated enclave that is concordant to the foliation of enclosing hornblende gneisses, Wadi Quseir, looking SE. b. One of the huge mappable enclaves within biotite gneisses, Wadi Amayiem, looking E. c. A lower thin band and an upper irregular block of amphibolites in quartzofeldspathic Wadi Nefuz, looking N. d. A variably-sized elongated and lensoidal blocks of amphibolite in biotite gneisses, looking NE.

\section{RESULTS}

\section{Petrography}

The amphibolite enclaves, composed mainly of hornblende and plagioclase, exhibit a wide variety of textures that reflects different protoliths. Four textural varieties were recorded: massive amphibolite, gneissose amphibolite, schistose amphibolite and banded amphibolite. Mineral abbreviations were adopted after Kretz (1983).

1- Massive Amphibolite. This is best recorded in Wadi Qusier, as a huge lens concordant to the gneisses' foliation. It is a coarse-grained cumulate, non-foliated and deformed. It is represented by the assemblage $\mathrm{Hbl}+\mathrm{Pl} \pm \mathrm{Bt}+\mathrm{Ep}+\mathrm{Ilm}+\mathrm{Prh}+\mathrm{Cht}$. The cumulus euhedral to subhedral hornblende $(60 \%)$ is dark green to yellowish-green, fractured and kinked. The intercumulus anhedral plagioclase $(35 \%)$ forms a sercitized and deformed phase (Fig. 3a). Pistachio-green epidote is recorded along the rims of 
Shallaly, N. A.

the hornblende. Prehnite forms small veinlets striking plagioclase and pod-like batches along the cleavage of kinked chloritized biotite (Fig. 3b) particularly near the boundaries with plagioclase.

2- Gneissose amphibolite. In Wadis Amayiem and Nefuz, this variety forms huge blocks that are concordant to the foliation in the host quartzofeldspathic gneisses. The rock is coarse-grained with an ill-defined lineation $\left(32^{\circ} / \mathrm{N} 83 \mathrm{E}\right)$ and is composed of $\mathrm{Hbl}+\mathrm{Act}+\mathrm{Pl}+\mathrm{Bt}+\mathrm{Sil}+\mathrm{Ep}+\mathrm{Sph}$. The hornblende is dark green to greyish-green, subhedral to anhedral and exhibits subgrain structure, with a rotation of about $5^{\circ}$. Actinolite is light green $\left(\mathrm{Z}^{\wedge} \mathrm{C} \sim 20\right)$ and forms a core in the hornblende or an overgrowth with epidote, ilmenite and rutile (Fig. 3c). The plagioclase (An28-33) is deformed and shows variable degrees of sericitization. Kinked reddish-brown biotite is rarely observed and is partially chloritized; epitaxial overgrowth of fibrolitic sillimanite along the mica cleavage is recorded (Fig. 3d). Apatite and sphene are enclosed in plagioclase and hornblende; quartz forms an interstitial phase.

3- Schistose Amphibolite. This variety is the most common. It crops out as a huge foliated dark green lens in Wadi Qusier $\left(60^{\circ} / \mathrm{N} 40 \mathrm{E}\right)$; in Wadi Nefuz, it forms elongated, concordant stretched blocks within quartzofeldspathic gneisses $\left(29^{\circ} / \mathrm{N} 70 \mathrm{E}\right)$; and highly flattened, few $\mathrm{cm}$-thick bands $\left(35^{\circ} / \mathrm{S} 75 \mathrm{E}\right)$ in quartzofeldspathic schists, in Wadi Amayiem. The rock is fine-grained, lineated and deformed; it preserves the typical amphibolite facies mineral assemblage of $\mathrm{Hbl}+\mathrm{Pl}+\mathrm{Sph}+\mathrm{Mag}+\mathrm{Ilm}+\mathrm{Ap}$. The hornblende varies between $50-80 \%$ of the rock and is strongly pleochroic: yellow $(\alpha)$, brownish-green $(\beta)$, olive-green $(\lambda)$; its nematoblastic fabric defines the main rock lineation (Fig. 3e). Small, elongated (up to $40 \%$ ) and slightly sercitized plagioclase (An38-45) grains are interstitially incorporated between the hornblende crystals. Sphene surrounds ilmenite crystals or occurs as small elongated grains that are intimately associated with hornblende and plagioclase and display shape preferred orientation (SPO, Fig. 3f).

4- Banded Amphibolite. The rock is best recorded along Wadi Feiran in the form of thin (15\% S50W) to huge $(72 \% \mathrm{~S} 70 \mathrm{~W})$ enclaves that are concordant to the foliation of the biotite-hornblende gneisses. The rock consists of the assemblage $\mathrm{Hbl}+\mathrm{Pl}+\mathrm{Di}+\mathrm{Sph}+\mathrm{Qtz}$ and exhibits a unique feature, namely an alternation of felsic and mafic bands. The felsic one is lensoidal, coarser in size, plagioclase-rich and wrapped around by the mafic band (Fig. 3g). It consists of large, deformed and saussuritized plagioclase with curved to lobate grain boundaries; with few light green epidotized hornblende crystals, sphene and quartz. The mafic bands are generally well foliated and composed of smaller olive-green hornblende that defines the foliation and traps few, anhedral, fine-grained and elongated interstitial plagioclase (An50). The hornblende crystals are deformed with the development of subgrains parallel to the main foliation and enclose anhedral diopside (Fig. 3h). Small veinlets of epidote or calcite, originating from the felsic bands strike the mafic ones.

\section{Bulk chemistry}

Geochemical data of 14 samples including major and trace elements as well as LREE with some crucial elemental ratios are listed (Table 1). Four samples were collected from Wadi Feiran, 4 from Wadi Qusier, 3 from Amayiem and 3 from Wadi Nefuz. As mentioned above, field investigation revealed that the different amphibolite enclaves and blocks have sharp contacts with their host para-gneisses, implying their magmatic origin. In order to verify the igneous nature of these enclaves geochemically, a plot of Ni$\mathrm{Zr} / \mathrm{TiO}_{2}$ (Winchester et al., 1980; Winchester and Max, 1982) is used; all samples have igneous precursors (Fig. 4a). These amphibolites are Hy to Ol-normative and show a wide range of composition (Table 1): $\mathrm{SiO}_{2}$ (41-58wt\%), moderate to high $\mathrm{Al}_{2} \mathrm{O}_{3}(11-17 \mathrm{wt} \%), \mathrm{TiO}_{2}(0.8-2.48 \mathrm{wt} \%), \mathrm{Fe}_{2} \mathrm{O}_{3}{ }^{\mathrm{t}}$ (5-20wt\%), $\mathrm{MgO}$ (3.8-12.3wt\%), $\mathrm{CaO}$ (4.5-11.6wt\%), $\mathrm{Na}_{2} \mathrm{O}$ (1.8-4.5 wt\%), $\mathrm{K}_{2} \mathrm{O}(0.68-2.89 \mathrm{wt} \%)$ and $\mathrm{Mg} \#$ (26-72). The samples have wide ranges of trace elements with $12-155 \mathrm{ppm} \mathrm{Ni}, 37-600 \mathrm{ppm} \mathrm{Cr}$ and $18-62 \mathrm{ppm} \mathrm{Co}, 127-$ 553ppm Sr, 9-81ppm Rb, 71-473ppm Ba, 2-14ppm Hf, 5-23ppm Nb, 28-55ppm Y, 8-30ppm La and 12$55 \mathrm{ppm} \mathrm{Ce}$. Harker bivariate diagrams are constructed to illustrate the chemical variation of some major oxides and important trace elements in the studied enclaves (Fig. 4b). Generally, there is a negative correlation of $\mathrm{SiO}_{2}$ with $\mathrm{TiO}_{2}, \mathrm{Fe}_{2} \mathrm{O}_{3}{ }^{\mathrm{t}}, \mathrm{CaO}, \mathrm{MgO}$, Ni, $\mathrm{Co}$ and a positive correlation with $\mathrm{Al}_{2} \mathrm{O}_{3}, \mathrm{Na}_{2} \mathrm{O}$, $\mathrm{K}_{2} \mathrm{O}, \mathrm{Ba}$, and $\mathrm{Rb}$. 
On the geochemistry of amphibolite enclaves

Fig. 3: a. Strained plagioclase with deformational twining, Massive amphibolite, PP. b. Curved podlike prehnite batches pressing the cleavage of kinked biotite flakes, Massive amphibolite C.N. c. An actinolite overgrowth around large hornblende with rutile and epidote, gneissose amphibolite, PP. d. A chloritized biotite flake with sillimanite growing along its cleavage, gneissose amphibolite, C.N. e. A general view of the schistose amphibolite showing its nematoblastic fabric, PP. f. A shape preferred oriented sphene defining the main foliation with hornblende and plagioclase, schistose amphibolite, PP. g. A lensoidal plagioclase surrounded by foliated hornblende, banded amphibolite, PP. h. Small diopside crystals infiltrating larger hornblende crystals, in banded amphibolite, C.N.
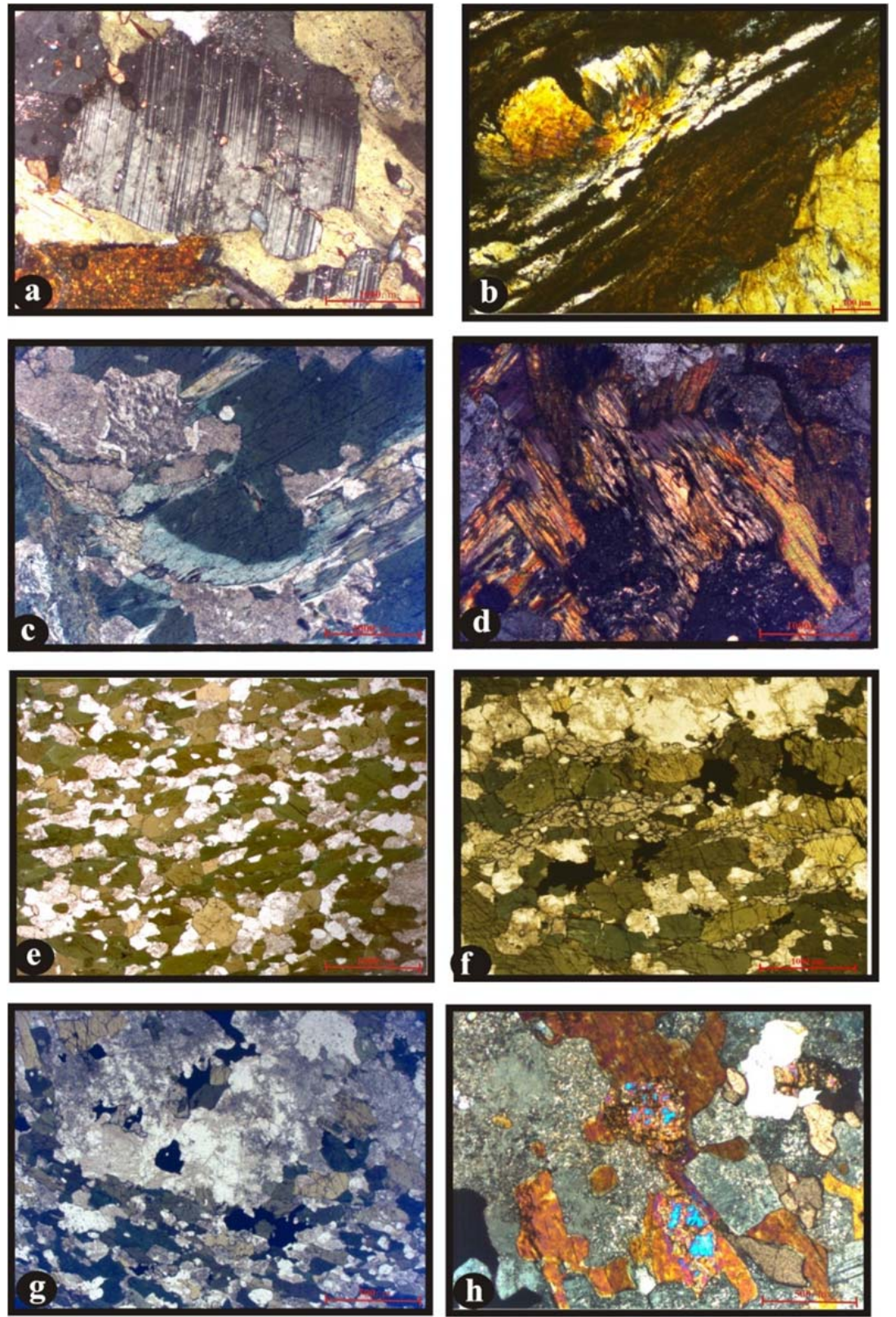

The primordial mantle normalized-spidergrams (after Wood et al., 1979) for the studied amphibolite enclaves (Fig.5a) is used to compare and highlight the nature of the subduction zone component if any. In general, the studied amphibolites are more or less comparable to one another with slight differences in the concentrations of some elements. The patterns of the studied rocks show an overall negative slope from left to right, as they exhibit enrichment of the LILE such as $\mathrm{K}, \mathrm{Rb}, \mathrm{Ba}, \mathrm{Th}$, and less markedly $\mathrm{La}, \mathrm{Ce}$ relative to the HFSE such as $\mathrm{Sr}, \mathrm{P}, \mathrm{Zr}$ and Ti. The majority of the studied samples exhibit a distinctive negative $\mathrm{Nb}$ anomaly (Fig. 5a), whereas three have a marked positive anomaly (Q3, Q4 and F6).

\section{DISCUSSION}

The studied enclaves are metamorphosed under amphibolite facies, so mobilization of some elements is possible, such as $\mathrm{Ca}, \mathrm{K}, \mathrm{Na}, \mathrm{Mg}$ and $\mathrm{Fe}$, that are susceptible to mobilization when metamorphosed under greenschist to amphibolite facies or affected by hydrothermal alteration (Pearce, 1996; Polat and Hofmann, 2003). Therefore, classification and setting of these rocks will be determined using the more immobile trace elements. 


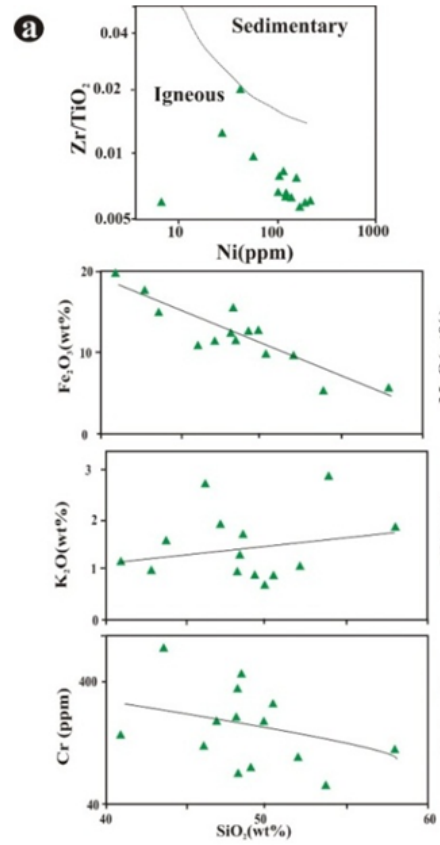

(1)
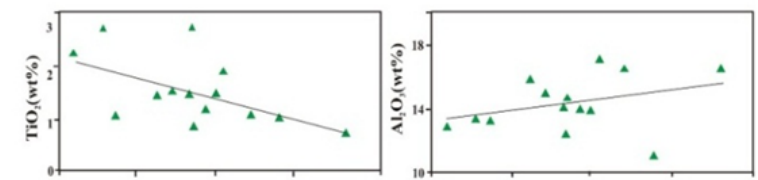

Fig. 4. a. $\mathrm{Ni}-\mathrm{Zr} / \mathrm{TiO}_{2}$ diagram to discriminate
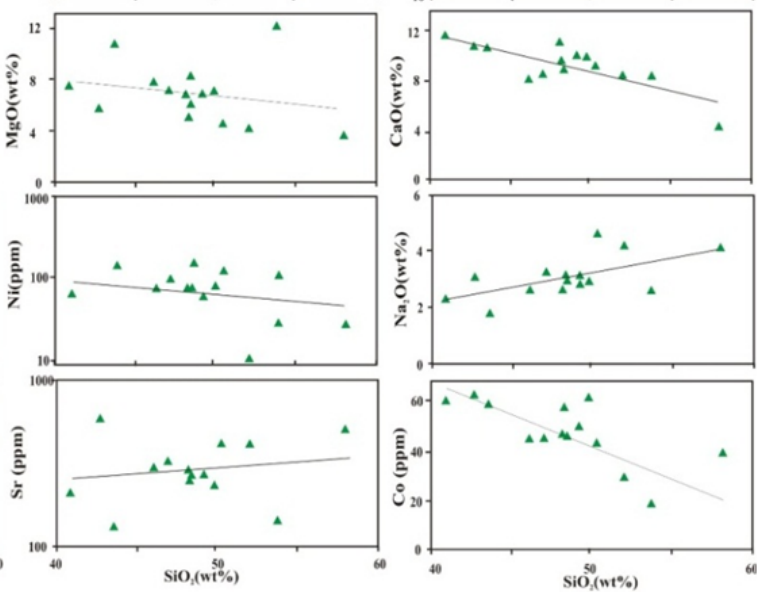

between para-

amphibolites and orthoamphibolites,

(Winchester and Max, 1982). b. Harker variation diagrams of major and important traces elements constructed for the studied amphibolites.

Fig. 5: a. primordial mantlenormalized spidergram (after, Wood et al., 1979) for the studied amphibolite enclaves. (samples Q3,Q4 and $\mathrm{F} 6$ are red), b. modified version (after Pearce, 1996) of the volcanic classification plot (after Winchester and Floyd, 1977), c. Al- Fet+Ti$\mathrm{Mg}$ volcanic rocks classification diagram (after Jensen, 1967), d. Q-P multicationic diagram for plutonic rock classification (after (a)

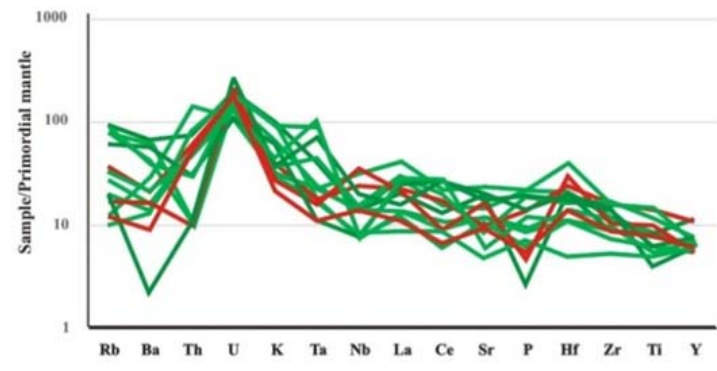

(D)

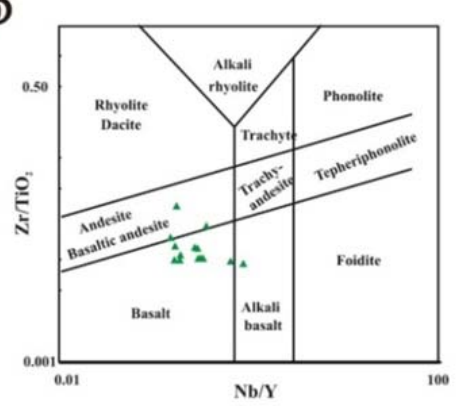

()

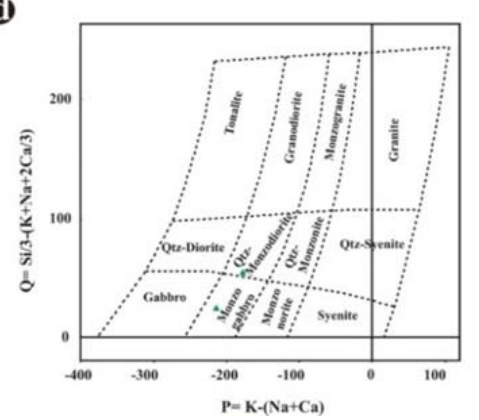

c

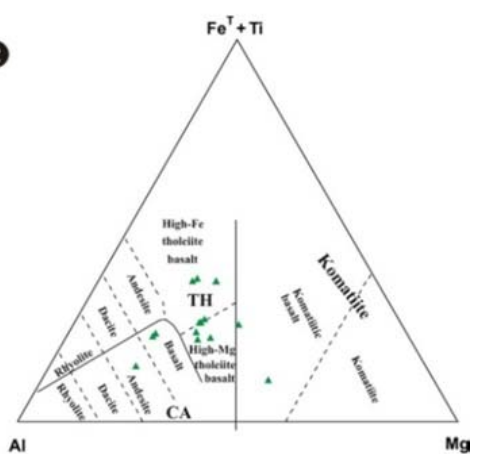

(

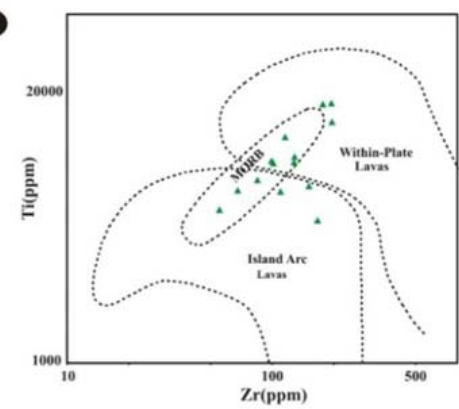


On the geochemistry of amphibolite enclaves

\section{Protolith nature}

For classification of these rocks the $\mathrm{Zr} / \mathrm{Ti}$ vs Nb/Y diagram of Winchester and Floyd (1977), modified by Pearce (1996), is used as this diagram classifies rocks based on their alkalinity measured by $\mathrm{Nb} / \mathrm{Y}$ and differentiation stage expressed by $\mathrm{Zr} / \mathrm{Ti}$. All the analyses have $\mathrm{Nb} / \mathrm{Y}<1$ suggesting the subalkaline affinity of the sampled enclaves. Most of them are basalts, except for samples F8 and F9 which are andesitic in composition (supported by their $\mathrm{SiO}_{2}$ content $>53 \mathrm{wt} \%$ ). The analysis of sample Q4 plots in the field of alkali basalt (Fig. 5b). These basalts are not homogeneous: on the $\mathrm{Fe}+\mathrm{Ti}-\mathrm{Mg}$-Al ternary diagram (Jensen, 1976), they range from high-Mg to high-Fe tholeiitic basalts. Analyses for three samples plot in the calcalkaline basalt (A6 and Q4) and andesite (F9) fields, while two analyses (Q2 and F8) plot in the field of komatiitic basalts (Fig. 5c). The latter samples, which have the highest $\mathrm{MgO}$ contents of $10.8-12.3 \mathrm{wt} \%$ and belong to the massive amphibolite and gneissose amphibolite, respectively, plot on the classification diagram of Debon and Le Fort (1983), in the monzogabbro and monzodiorite fields, respectively (Fig. 5d). On the Th-Co diagram (Hastie et al., 2007, not shown), these two samples are of high calc-alkaline composition.

\section{Tectonic setting}

The tectonic environment of the studied enclaves can be envisaged through the use of several immobile trace element-based diagrams. On the Zr-Ti discrimination diagram Pearce (1982), three samples (N2, Q6 and F6) plot in the within-plate field, samples (F8, F9 and A6) plot in the island arc lavas field, whereas the rest of the samples plot in the MORB field that intersects with the other two fields (Fig.5e). Using the $\mathrm{Zr}$ vs $\mathrm{Zr} / \mathrm{Y}$ relation (Pearce and Norry, 1979), the studied rocks reveal the presence of two precursor groups: within- plate basalts and island arc basalts (Fig. 6a). Moreover, the diverse nature of the basaltic precursors of the studied enclaves is confirmed using the Y-La-Nb diagram after Cabanis and Lecolle (1989). On this diagram (Fig. 6b), the studied rocks cluster in the 1A (island arc), 2A (continental) and 2B (back-arc) fields. The island arc samples are andesite-andesitic basalts and monzodiorite (F8). The two high-MgO samples are considered geochemically as appinitic rocks, as defined by Murphy (2013), due to their high Ni (54-137ppm), Cr (114-600ppm), V (172->262ppm) and Mg\# (44-72) comparable to the Caledonian appinite suite (Stern et al., 1989). The V/Ti values of the studied rocks, which range between 20-50; and are characteristic of MORB, back-arc basins and continental basalts, as suggested by Shervais (1982).

\section{Magma source compositions}

The spiked nature of the spider diagram and the enrichment of the whole pattern of incompatible trace elements (LILE > HFSE) with respect to primordial mantle (Fig. 5a), indicate that these rocks were evolved from an enriched mantle source. The $\mathrm{Th} / \mathrm{Nb}$ ratio is considered a crucial factor in determining the influence of subduction on modifying the underlying mantle. Th is the least affected by hydrothermal fluids compared to other LILEs and so it might indicate mantle metasomatism (Lafleche et al., 1992); whereas $\mathrm{Nb}$ is immobile in fluids and is less abundant in sediment-derived melts (Raza and Mondal, 2019). The $\mathrm{Th} / \mathrm{Nb}$ ratio of $\mathrm{N}-\mathrm{MORB}$ is 0.05 , while that of $\mathrm{E}-\mathrm{MORB}$ is 0.08 . Most of the studied enclaves have a relatively high $\mathrm{Th} / \mathrm{Nb}$ ratio of 0.38 to 1 (Table 1 ), that would imply metasomatism of the PanAfrican mantle by subduction components. However, two samples (A6 and Q4) have a Th/ $\mathrm{Nb}$ range of 0.04-0.08 close to that for N-MORB. This finding would attest to the variable heterogeneous nature of the Pan-African mantle source. The increase of this ratio from oceanic basalts to subduction-related basalts is similar to that found for the Archean Fiskenaesset basalts (Polat et al., 2007) and the Mauranipur-Babina Greenstone Belt (Raza and Mondal, 2019). The composition of the mantle source may be modified by crustal contamination (Wilson, 1989). Hofmann et al. (1986) determined the $\mathrm{Nb} / \mathrm{U}$ and $\mathrm{Ce} / \mathrm{Pb}$ ratios for MORBs and OIBs; although these basaltic magmas were generated from different mantle sources, yet they have uniform ratio values of $47 \pm 10$ and $25 \pm 5$, respectively. The studied enclaves have very low $\mathrm{Nb} / \mathrm{U}$ and $\mathrm{Ce} / \mathrm{Pb}$ ratios of 1-6 and 1.4-10 (Table 1), respectively; these lower ratios are consistent with the assumption that during plate subduction, $\mathrm{U}$ and $\mathrm{Pb}$ are more mobile than $\mathrm{Nb}$ and $\mathrm{Ce}$, as proposed by McCulloch and Gamble (1991) and Pearce and Peate (1995). These values are close to those for continental crust and island arc rocks, for which these ratios average 4 and 9, respectively (Hofmann, 1997). Consequently, the underlying mantle of the study area was modified by crustal material. Wilson 
Shallaly, N. A.

(1989) stated that contamination of magmas by crustal material is supported by the presence of a $\mathrm{Nb}$ trough on spidergrams; a remarkable $\mathrm{Nb}$ trough is recorded for the majority of the studied samples (Fig.5a).

\section{Fractional crystallization}

Magmas are said to be primary if they are produced through the partial melting of the upper mantle without modification by other processes, such as fractional crystallisation, magma mixing, crustal assimilation (e.g. Langmuir et al., 1992; Stracke and Bourdon, 2009). In this case, they should have high $\mathrm{Mg \# s}$ of (68-72) and Ni concentrations of 300-500 ppm (Frey et al., 1978). Most of the analysed rocks have relatively low $\mathrm{MgO}$ contents $(3.8-8.4 \mathrm{wt} \%)$ and low $\mathrm{Ni}(<300 \mathrm{ppm})$, which means that their magmas are not of primary origin and must have undergone secondary processes, such as fractionation. The good negative correlation of $\mathrm{SiO}_{2}$ with $\mathrm{TiO}_{2}, \mathrm{Fe}_{2} \mathrm{O}_{3}{ }^{\mathrm{t}}, \mathrm{CaO}, \mathrm{MgO}$ and $\mathrm{Ni}$ (Fig. 4b), suggests that the studied rocks have undergone calcic plagioclase, clinopyroxene, olivine and magnetite fractional crystallization en route to the surface. Moreover, a fractionation process by was also confirmed by studying the $\mathrm{TiO}_{2}, \mathrm{Fe}_{2} \mathrm{O}_{3}{ }^{\mathrm{t}}, \mathrm{P}_{2} \mathrm{O}_{5}$ and $\mathrm{CaO} / \mathrm{Al}_{2} \mathrm{O}_{3}$ trends vs $\mathrm{MgO}$ (Fig. 6c). These trends exhibit inflection at about $6 \mathrm{wt} \% \mathrm{MgO}$, as they show a positive correlation below this value and a negative relation above it. Such a relation can be explained by the onset of crystallization of plagioclase, hornblende and sphene phenocrysts as well as apatite crystals in the more evolved liquids, as reported for the arc-related magmas, either of island arc affinity such as the Sanda arc or of active continental margins such as that of the Andes or back-arc settings such as the Bonin island, (Wilson, 1989).

\section{Depth and degree of partial melting}

Major and trace elements are also important in determining the degree of, and the depth at which, partial melting of mantle sources takes place (Baker and Stolper, 1994). On the $\mathrm{Zr}$ vs $\mathrm{Zr} / \mathrm{Y}$ diagram (after Pearce and Norry, 1979), it is clear that most of the samples follow curve I (Fig. 6d) which show slight increase in the $\mathrm{Zr} / \mathrm{Y}$ ratio (1.7-5.4), with increasing $\mathrm{Zr}$ contents (55-193). This probably reflects a variable degree of partial melting of a mantle source containing $60 \%$ olivine, $20 \%$ orthopyroxene, $10 \%$ clinopyroxene and $10 \%$ plagioclase, such as the case for Archean mantle sources reported by Sun and Nesbitt (1977). This assemblage is consistent with partial melting at $<10 \mathrm{kbar}$ in the shallow plagioclase lherzolite mantle field at an estimated depth of about $10-25 \mathrm{~km}$. Jaques and Green (1980) proposed that different degrees of partial melting in the plagioclase peridotite field produce magnesian quartz tholeiite, olivine-poor tholeiite and even basaltic or pyroxenitic komatiite at a higher degree of melting (30-40\%).

\section{Petrogenetic implications with respect to Pan-African amphibolites from south Sinai}

The Pan-African amphibolites in south Sinai are mainly of basaltic to andesitic composition. They are exposed either in the form of metamorphosed lava flows and tuffs as in Wadi Kid, SE Sinai (lower metavolcanic unit "LMV", Shallaly, 2007), in Wadi Malhaq, SE Sinai (Abu El-Enen, 2008) and in Wadi Sa'al, Central south Sinai (Hassen et al. 2004; Abu Anbar et al., 2009); or as blocks and enclaves in gneisses as in Wadi El-Seih, west central Sinai (Abd El-Karim,2003), Wadi Feiran (Abu Anbar and Abd El-Wahed, 2004; Zayed, 2006; El-Tokhy et al. 2010) and in schists as in Wadi Um Zeriq, SE Sinai (Shallaly, 2007). Compared to the amphibolites from Wadi Kid, Malhaq, El Sieh and Um Zeriq (Fig.6c), it is concluded that the studied enclaves fall into three groups: the first group with a low $\mathrm{MgO}$ content $(<$ $6 \mathrm{wt} \%)$, resembles the metavolcanic tuffs and flows of Wadis Kid, Malhaq and Sa'al. The second group with a moderate $\mathrm{MgO}$ content (6-8wt\%), is similar to Wadi El-Sieh amphibolite enclaves. The third group is unique with a high $\mathrm{MgO}(10-12 \mathrm{wt} \%)$; it is comparable to the exotic blocks within the garnet schists of Wadi Um Zeriq. The metavolcanic rocks are said to be tholeiitic to calc-alkaline and arc-related (e.g.

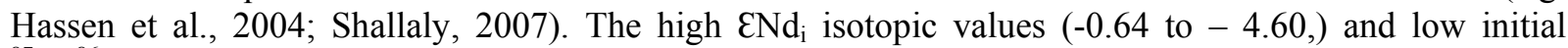
${ }^{87} \mathrm{Sr} /{ }^{86} \mathrm{Sr}(0.702-0.704)$ of the Wadi Sa'al volcanics led Abu Anbar et al. (2009), to suggest that these arcrelated rocks originated from a mantle source in an interoceanic setting. On the other hand, isotopic compositions of the Wadi Feiran amphibolites reported by Abu Anbar et al. (2004), suggested the

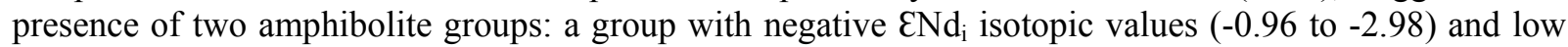


On the geochemistry of amphibolite enclaves

initial ${ }^{87} \mathrm{Sr} /{ }^{86} \mathrm{Sr}(0.703$ to 0.704$)$, that reflect a mantle origin having an age of $1118 \pm 222 \mathrm{Ma}$. The second group was different and had a $\mathrm{ENd}_{\mathrm{i}}$ value of -4.64 and low initial ${ }^{87} \mathrm{Sr} /{ }^{86} \mathrm{Sr} 0.710$.

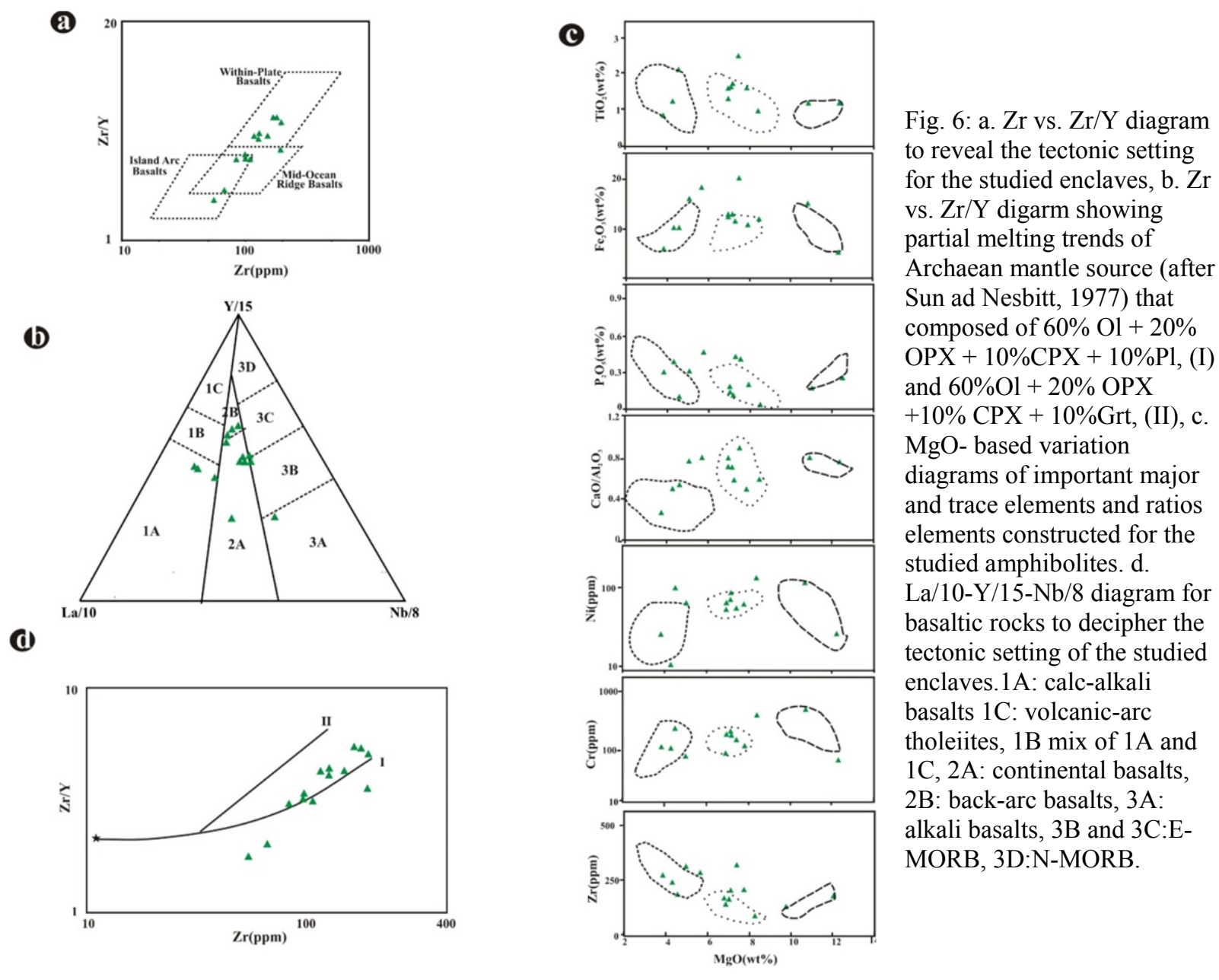

Both El-Sieh amphibolites (Abd El-Karim, 2003) and the present studied group of moderate $\mathrm{MgO}$ contents $(6-8 \mathrm{wt} \%)$ have a transitional continental within-plate origin. The appinitic rocks are similar geochemically to the komatiitic basalts and boninite blocks in Wadi Um Zeriq and to other appinitic rocks in Sinai. Both, possibly cogenetic, appinites and boninites are subduction-related and evolve from an asthenospheric mantle that was hydrated and metasomatized prior to partial melting by subduction (Crawford et al., 1989; Murphy, 2013.). Parman et al. (2001) suggested that Proterozoic/Phanerozoic rocks should include an ultramafic assemblage that is intermediate between recent boninites and Archaean komatiite- bearing sequences. Appinitic diorites were described as enclaves in the Feiran area (Zayed, 2006), whereas an appinitic suite including gabbros and diorites was recorded only in Wadi Nasb, south Central Sinai (Gahlan et al., 2017). However, these rocks differ from the studied appinitic enclaves as they are undeformed and unmetamorphosed and have intrusive contacts with their adjacent metamorphic country rocks. In the present author's opinion, the presence of appinites, as in Wadis Feiran and Nasb, and of komatiitic basalts and boninites as in Wadi Um Zeriq, would imply the presence of a primary mantle source in addition to the more evolved magma that gave rise to the rest of enclaves. In conclusion, Pearce (1996) argued that when samples plot in transitions between MORB, WPB and VAB, their possible setting is either an attenuated back-arc continental lithosphere or areas of plume-subduction interaction. The former case is mainly associated with arc-volcanogenic sedimentation while in the latter areas these rocks are mostly associated with high-MgO lavas such as boninites and related rocks (Pearce, 1996).

As mentioned earlier, the studied enclaves are said to be of back-arc setting. This is in accordance with the depositional environments of the enclosing Wadi Feiran para-gneisses and schists, which Zayed 
Shallaly, N. A.

(2006) concluded were deposited in a back-arc basin. This back-arc setting is reinforced by unusual geochemical characteristics that the presence of some samples resemble within-plate rocks and others are more akin to arc-related rocks. Moreover, the presence of high-MgO magmas and absence of bimodal volcanism would imply an area of plume-subduction interaction. In the author's opinion, the study area is a transition between a proper back-arc continental lithosphere and an area of plume-subduction interaction.

The proposed model for the emplacement of the rocks that gave rise to the amphibolite enclaves is summarized (Fig. 7). During the deposition of the back-arc sediments which metamorphosed latter to the gneisses of the Wadi Feiran and its tributaries as reported by Zayed (2006), the subducted oceanic slab of the Mozambique crust result in the partial melt of the mantle wedge. The composition of this melt was $\mathrm{MgO}$ - rich, that find its way to the arc crust and form the appinitic monzogabbros and monzodiorites. The interaction of this melt with the sub-arc crustal material produced the calc-alkaline andesite and basalt enclaves. On the other hand a mantle plume beneath the back-arc basin resulted in the formation of a partial melt at the base of the crust, this produced the basaltic rocks with the within-plate affinity (Fig. 7).

Fig. 7: A proposed tectonic model for the Wadi Feiran amphibolite enclaves and their relation to Pan-African magmatism (adapted after Zhu et al., 2019).

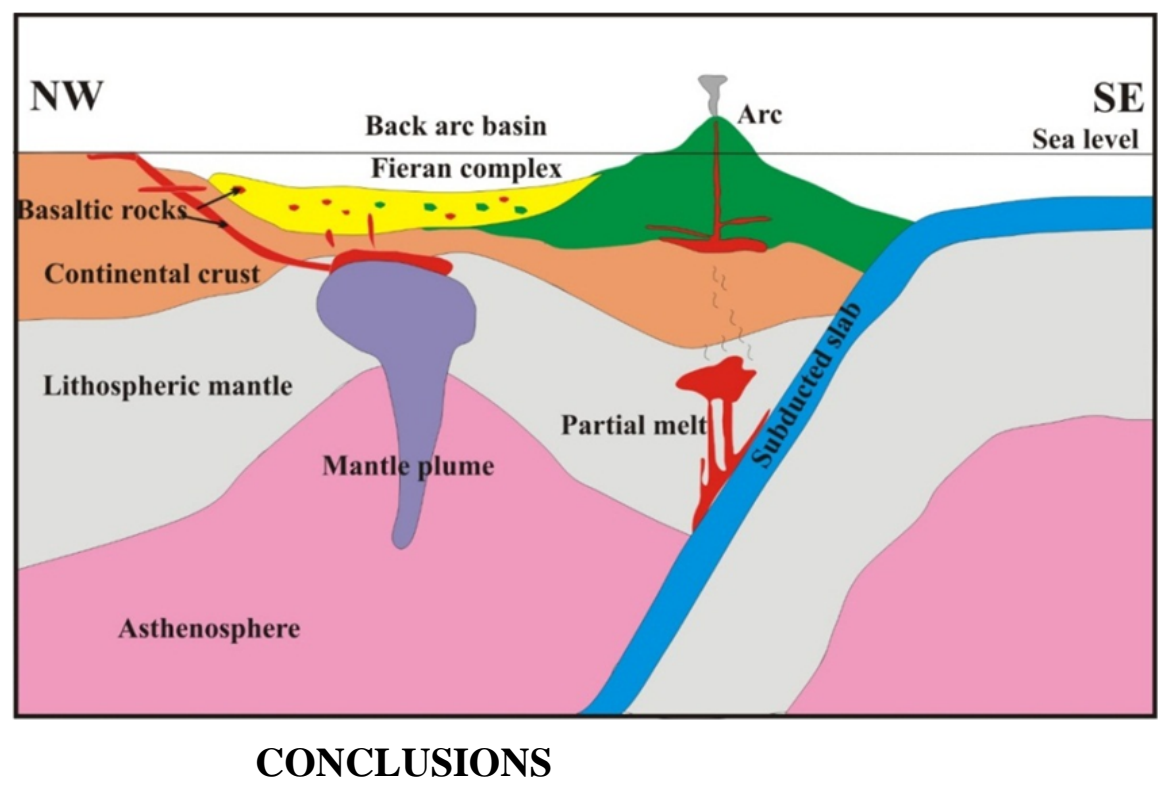

1. Variably-sized, elongated enclaves of amphibolites are recorded in gneisses and schists along Wadi Feiran and its tributaries Wadies Qusier, Amayiem and Nefuz. Their elongation is concordant to the foliation of the host $\mathrm{Hb}-, \mathrm{Hb}-\mathrm{Bt}$ and $\mathrm{Bt}-$ gneisses and schists along sharp contacts.

2. The amphibolites are divided texturally into four groups namely: massive amphibolite, gneissose amphibolite, schistose amphibolite and banded amphibolite.

3. These enclaves are of igneous origin, mostly basaltic to andesitic rocks; in addition, two coarse grained varieties classify geochemically as high- $\mathrm{MgO}$ appinitic monzodiorite and monzogabbro.

4. Geochemically, these enclaves are heterogeneous and were formed in an environment that is transitional between a back-arc continental lithosphere and an area of plume-subduction interaction. Its underlying mantle had two components: a primary mantle source that was hydrated prior to melting and gave rise to the appinitic rocks. The second mantle source is more enriched and was modified by different degrees of partial melting, crustal contamination and fractional crystallization, to give rise to the basaltic and andesitic enclaves.

5. The presence of high-MgO rocks, namely the studied Wadi Feiran appinitic monzogabbro and monzodiorite enclaves, the appinite suite in Wadi Nasb and the komatiitic basalt and boninite exotic blocks in Wadi Um Zeriq, witnesses the existence of a primary magma source in the Pan-African mantle of the Kid-Sa'al-Feiran island arcs. 
On the geochemistry of amphibolite enclaves

\section{ACKNOWLEDGMENTS}

This research was supported by the German Academic Exchange Service (DAAD) for short-term scholarships. The author is deeply indebted to Prof. Dr. A. Hafez for critically reviewing the manuscript. The author would like to acknowledge the help of Dr. H. Abu Salem during field work; and Prof. Dr. C. Beier and Ms. M. Hertel, GeoZentrum Nordbayern, Erlangen University, for technical support of the chemical analyses.

\section{REFERENCES}

Abd El-Karim, A. M., (2003): Mineralogy, geochemistry and petrogenetic implications of amphibolites from Wadi El-Seih area, central west Sinai, Egypt. Egypt. J. Geol. 47(1), 25-39.

Abu-Alam, T.S., Stüwe K. and Hauzenberger, C., (2010): Calc-silicates from Wadi Solaf region, Sinai, Egypt. J. Afric. Earth Sci. 58, 475-488.

Abu Anbar, M. and Abd El-Wahed, M., (2004): Geochemistry, mineralogy, and evolution of Feiran gneisses and amphibolites, SW Sinai, Egypt. $6^{\text {th }}$ Inter. Conf. Geochem., Alex. Univ., Egypt, 747-776.

Abu Anbar, M., Finger, F. and Solís Pichardo, G., (2009): Evolution of the metamorphosed volcanosedimentary rocks in Sa'al area, southern Sinai, Egypt: implications from lithology, geochemistry, mineralogy, P-T conditions and age dating. Egypt. J. Geol. 53, 1-35.

Abu Anbar, M., Solis Pichardo, G., Hernandez Bernal, M.S., Morales Contreras, J. M. and Hernandez Treviño, T. H., (2004): Sm-Nd and Rb-Sr isotopes of Feiran gneisses and amphibolites: evidences of Pre-Pan-African continental crust in Sinai, Egypt. $6^{\text {th }}$ Inter. Conf. Geochem., Alex. Univ., Egypt, 727745.

Abu El-Enen, M.M., (2008): Geochemistry and metamorphism of the Pan-African back-arc Malhaq volcano-sedimentary Neoproterozoic association, W. Kid area, SE Sinai, Egypt. J. Afric. Earth Sci. $51,189-206$.

Ahmed, A. A., (1970): Geology of the area around Feiran Oasis, Sinai, Egypt. Ph. D. thesis, Assiut Univ., $543 \mathrm{p}$.

Akaad, M. K. and Noweir, A. M., (1980): Geology and lithostratigraphy of the Arabian Desert orogenic belt of Egypt between latitudes $25^{\circ} 35^{\prime}$ and 36 30' N. Bull. Inst. App. Geol. Saudi Arabia 3, 127-135.

Akaad M.K., El-Gaby S. and Abbas A.A., (1967): Geology and petrology of the migmatites around Feiran Oasis, Sinai [J]. Assiut Sci. Techn. Bull. 10, 67-87.

Basta, E. Z., Takla, M. A. and Shenouda, H. H., (1981): Opaque mineralogy of some ortho- and paraamphibolites and related rocks, Eastern Desert, Egypt. Delta J. Sci. 5,315-337.

Baker, M.B. and Stolper, E.M., (1994): Determining the composition of high-pressure mantle melts using diamond aggregates. Geochim. Cosmochim. Acta 58, 2811-2827.

Belasy, M.R., (1991): Geology, petrography and geochemistry of the metamorphic rocks of wadi FeiranSolaf area, SW Sinai Egypt. Ph.D. thesis, Zagazig Univ., 386p.

Bielski, M., (1982): Stages in the evolution of the Arabian-Nubian massif in Sinai. Ph. D. thesis, Hebrew Univ. Jerusalem, 155p.

Cabanis, B. and Lecolle, M., (1989): Le diagramme La/10-Y/15-Nb/8; un outil pour la discrimination des series volcaniques et la mise en evidence des processus de mélange et/ou de contamination crustale. Comptes Rendus de 1'Academie des Sciences, Serie 2, Mecanique, Physique, Chimie, Sciences de L'Universe, Sciences de la Terre, 309 (20), 2023-2029.

Chopin, C., (2003): Ultrahigh-pressure metamorphism: tracing continental crust into the mantle. Earth Planet. Sci. Lett. 212, 1-14.

Crawford, A.J., Falloon, T.J. and Green, D.H. (1989): Classification, petrogenesis and tectonic setting of boninites. In., A. J. Crawford, (ed.), Boninites and Related Rocks. Unwin Hyman, London, 1-49.

Debon, F. and Le Fort, P., (1983): A chemical mineralogical classification of common plutonic rocks and associations. Transactions of the Royal Society of Edinburgh: Earth Sciences 73, 135-149.

El-Gaby, S. and Ahmed, A. M. A., (1980): The Feiran-Solaf gneiss belt, southwestern Sinai, Egypt. In, P.G. Coora and S.A. Tahoun(ed.), Evolution and mineralization of the Arabian-Nubian Shield. Inst. App. Jeddah, Bull. 3, Pergamon Press, 4, 95-105.

El-Gaby, S. and Habib, M., (1980): The eugeosynchnal filling of Abu Ziran Group in the area SW of Port Safaga, Eastern Desert, Egypt. Bull. Inst. App. Geol. Saudi Arabia 3,137-142. 
Shallaly, N. A.

El-Gaby, S., List, F.K. and Tehrani, R., (1990): The basement complex of the Eastern Desert and Sinai. In, R. Said, (ed.), The Geology of Egypt. Balkema, Rotterdam, 175 - 184.

El-Shafei, M. K. and Kusky, T. M., (2003): Structural and tectonic evolution of the Neoproterozoic Feiran- Solaf metamorphic belt, Sinai Peninsula: Implication for the closure of the Mozambique Ocean. Precamb. Res. 123, 269-293.

El-Tokhi, M., (1990): Petrographical, geochemical and experimental studies on the migmatite rocks of Wadi Feiran, Southwest Sinai, Egypt. Ph. D. thesis, Karlsruhe Univ., Germany, 99p.

El-Tokhi, M., Amin, B., Alabeed,S. and Musallam., A. (2010):Geochemistry and mineral chemistry of Pan-African amphibolites of South Sinai, Egypt. Chin. J. Geochem. 29, 246-254.

Eyal, M., Be'eri-Shlevin, Y., Eyal, Y., Whitehouse, M. J. and Litvinovsky, B., (2014): Three successive Proterozoic island arcs in the northern Arabian-Nubian Shield: Evidence from SIMS U-Pb dating of zircon. Gond. Res., 25, 338-357.

Frey, F. A., Chappell, B. W. and Roy, S. D., (1978): Fractionation of rare-earth elements in the Tuolumne intrusive series, Sierra Nevada batholith, California. Geology 6, 239-242.

Gahlan, H. A., Obeid, M. A., Azer, M. K. and Asimow, P. D., (2017). An example of post- collisional appinitic magmatism with an arc-like signature: The Wadi Nasb mafic intrusion, north ArabianNubian Shield, south Sinai, Egypt. Inter. Geol. Rev., DOI: 10.1080/00206814.2017.1360804.

Hamimi, Z., Abd El-Wahed, M. A., Gahlan, H. A. and Kamh, S. Z., (2019): Tectonics of the Eastern Desert of Egypt: Key to Understanding the Neoproterozoic Evolution of the Arabian-Nubian Shield (East African Orogen). in A., Bendoud, Z., Hamimi, M., Hamoudi, S., Djemai and B. Zoheir (eds.), Geology of the Arab World-An Overview, Springer Geology, 1-81, Springer Geology, http://doi.org/10.1007/978-3-319-96794-3-1

Hashad, M. H., Hassen, I. S. and El Kalioubi, B., (2001): Petrology and mineralogy of calc- silicate gneisses and their significance as indicators of metamorphism in southeastern Sinai. Egypt. Mineral. $13,187-223$.

Hassan, M. A. and Hashad, H. H., (1990): Precambrian of Egypt. in R. Said (ed.), Geology of Egypt. Balkema, Rotterdam, The Netherlands, 210-245.

Hassen, I. S., Ibrahim, S. K. and Elemer, P. M., (2004): Evolution and origin of the metavolcanics at Wadi Sa'al area, South Sinai, Egypt. Ann. Geol. Surv. Egypt. XXVII, 61-78.

Hastie, A. R., Kerr, A. C., Pearce, J. A. and Mitchell, S. F., (2007): Classification of altered volcanic island arc rocks using immobile trace elements: Development of the Th-Co discrimination diagram. J. Petrol., 48/12, 2341-2357.

Hofmann, A.W., (1997): Mantle geochemistry: the message from oceanic volcanism. Nature, 385, 219229.

Hofmann, A. W., Jochum, K.P., Seufert, M. and White, W. M., (1986): Nb and Pb for the oceanic basalts: new constraints on mantle evolution. Earth Planet. Sci. Lett. 79, 33-45.

Jaques, A. L. and Green, D. H., (1980): Anhydrous melting of peridotite at $0-15 \mathrm{~Kb}$ pressure and the genesis of tholeiitic basalts. Contrib. Mineral. Petrol., 73/3, 287-310.

Jensen, L.S., (1976): A new cation plot for classifying subalkalic volcanic rocks. Ontario. Div. Mines, MP, 66, 1-22.

Kabesh, M., (1993): Geological, petrological and geochemical studies on migmatitic rocks of Southwest Sinai, Egyot. Ph. D. thesis, Cairo Univ., Giza, Egypt, 180p.

Kretz, R., (1983): Symbols for rock-forming minerals. Am. Mineral., 68, 277- 279.

Lafleche, M. R., Dupuy, C. and Dostal, J., (1992): Tholeiitic volcanic rocks of the late Archaean Blake River group, southern Abitibi greenstone belt: Origin and geodynamic implications. Can. J. Earth Sci. 29, 1448-1458.

Langmuir, C. H., Klein, E. M., and Plank, T., (1992): Petrological systematics of Mid-Ocean Ridge Basalts: Constraints on melt generation beneath ocean ridges. Geophys. Mono. Series 71, doi: 10.1029/GM07, 183p.

Liégeois, J. P. and Stern, R. J., (2010): Sr-Nd isotopes and the geochemistry of granite- Gneiss complexes from the Meatiq and Hafafit domes, Eastern, Desert, Egypt: no evidence for pre-Neoproterozoic crust. J. Afric. Earth Sci. 57, 31-40. 
On the geochemistry of amphibolite enclaves

Maboko, M. A. H., (2000): Nd and Sr isotopic investigation of the Archean-Proterozoic boundary in north eastern Tanzania: constraints on the nature of Neoproterozoic tectonism in the Mozambique Belt. Precamb. Res. 102, 87-98.

Meschede, M.,(1986): A method of discriminating between different types of mid-ocean ridge basalts and continental tholeiites with the Nb-Zr-Y diagram. Chem. Geol. 56, 207-218.

Murphy, J.B., (2013): Appinite suites: A record of the role of water in the genesis, transport, emplacement and crystallization of magma. Earth Sci. Rev. 119, 35-59.

McCulloch, M. T. and Gamble, J. A., (1991): Geochemical and geodynamical constraints on subduction zone magmatism. Earth Planet. Sci. Lett. 102, 358-374.

Neumayr, P., Mogessie, A., Hoinkes, G. and Puhl, J., (1996: Geological setting of the Meatiq metamorphic core complex in the Eastern Desert of Egypt based on amphibolite geochemistry. J. Afric. Earth Sci. 23 (3), $331-345$.

Parman, S. W., Grove, T. L. and Dann, J. C., (2001): The production of Barberton komatiites in an Archean subduction zone. Geophys. Res. Lett. 28 (13), 2513-2516.

Pearce, J. A., (1982): Trace element characteristics of lavas from destructive plate boundaries. In R. S. Thorpe (ed.), Andesites and related rocks. John Wiley and Sons, London, 525-548.

Pearce, J.A., (1996): A user's guide to basalt discrimination diagrams. In D.A. Wyman, (ed.), Trace element geochemistry of volcanic rocks: application for massive sulphide exploration. Geol. Assoc. Can., short course notes, 12, 79-113.

Pearce, J.A. and Norry, M.J., (1979): Petrogenetic implications of Ti, Zr, Y and Nb variations in volcanic rocks. Contrib. Miner. Petrol. 69 (1),33-47.

Pearce, J. A. and Peate, D. W., (1995): Tectonic implications of the composition of volcanic arc magmas. Ann. Rev. Earth Planet. Sci. 23, 251-285.

Pin, C. and Veilzeuf, D., (1983): Granulites and related rocks in Variscan Median Europe: A dualistic interpretation. Tectonophysics 93, 47-74.

Polat, A., and Hofmann, A. W., (2003): Alteration and geochemical patterns in the 3.7-3.8 Ga Isua greenstone belt, West Greenland. Precamb. Res. 126, 197-218.

Polat, A., Appel, W. U. P., Frei, R., Pan, Y., Dilek,Y. Ordóñez-Calderó C. J., et al., (2007): Field and geochemical characteristics of the Mesoarchean (3075 Ma) Ivisaartoq greenstone belt, southern West Greenland: Evidence for seafloor hydrothermal alteration in supra-subduction oceanic crust. Precamb. Res. 11, 69-91.

Raza, A. and Mondal, M. E., (2019): Geochemistry of the mafic metavolcanic rocks of mauranipurBabina greenstone Belt, Bundelkhand Craton, Central India: Implication for tectonic settings during the Archaean. Springer, In, M. E. A. Mondal (ed.), Geological Evolution of the Precambrian Indian Shield, Society of Earth Scientists Series, https://doi.org/10.1007/978-3-319-89698-4-22.

Saha, L., Bhowmik, S. K., Fukuoka, M. and Dasgupta, S., (2008): Contrasting Episodes of Regional Granulite-Facies Metamorphism in Enclaves and Host Gneisses from the Aravalli-Delhi Mobile Belt, NW India. J. Petrol. 49(1), 107-128.

Schandelmeier, H., Darbyshire, D. P. F., Harms, U. and Richter, A., (1988): The east Sahara Craton; evidence for Pre-Pan-African crust in NE Africa west of the Nile. In, S. El-Gaby, (ed.), The Pan African belt of Northeast Africa and Adjacent Area, 69-94. Friedr. Viewegsohn, Braunschweig/Wiesbaden.

Shallaly N. A., (2007): Geology of central Wadi Kid area, southern Sinai, Egypt. Ph D. thesis (unpubl.), Cairo University, Giza, Egypt, 298p.

Shervais, J.W., (1982): Ti-V plots and the petrogenesis of modern and ophiolitic lavas. Earth Planet. Sci. Lett. 59, 101-118.

Stracke, A. and Bourdon, B., (2009): The importance of melt extraction for tracing mantle heterogeneity. Geochim. Cosmoch. Acta 73, 218-238.

Stern, R. J. and Manton, W. I., (1987): Age of Feiran basement rocks, Sinai: implication for Late Precambrian crustal evolution in the northern Arabian-Nubian Shield. J. Geol. Soc. Lond. 144, 569575. 
Shallaly, N. A.

Stern, R. A., Hanson, G. N. and Shirey, S. B., (1989): Petrogenesis of mantle-derived, LILE enriched Archaean monzodiorites and trachyandesites (sanukitoids) in Southwestern Superior Province. Canad. J. Earth Sci., 26, 1688-1712.

Sultan, Y. M. H., (2003): Structural studies of Wadi Feiran-Wadi El Sheikh area, South Sinai, Egypt. M. Sc. thesis, Suez Canal Univ., Ismailia, Egypt, 140p.

Sun, S.S. and Nesbitt, R.W., (1977): Chemical Heterogeneity of Archaean Mantle, Composition of Earth and Mantle Evolution. Earth Planet. Sci. Lett. 35 (3), 429-448.

Surour, A., (1995): Medium- to high-pressure garnet-amphibolites from Gebel Zabara and Wadi Sikait south Eastern Desert, Egypt. J. Afric. Earth Sci. 21/3, 443-457.

Takla, M. A., Basta, F. F. and El-Maghraby, A. M., (1992): Contribution to the geology of Wadi Ghadir area, Eastern Desert, Egypt. Egypt. J. Geol. 36,373-392.

Wilson, M., (1989): Igneous Petrogenesis. Chapman and Hill, London., 466p.

Winchester, J. A. and Floyd, P. A., (1977): Geochemical discrimination of different magma series and their differentiation products using immobile elements. Chem. Geol. 20, 325-343.

Winchester, J. A., and Max, M. D., (1982): The geochemistry and origin of the Precambrian rocks of the Rosslare Complex S.E. Ireland. J. Geol. Soc. Lond. 139, 309-319.

Winchester, J. A., Park, K. G., and Holland, J. G., (1980): The geochemistry of Levisian semipelitic schists from the Gairloch district western Ross. Scot. J. Geol. 16, 165-179.

Wood, D.A., Tarney, J., Varet, J., Saunders, A.D., Bougault, H., Joron, J.L., Treuil, M. and Cann, J.R., (1979): Geochemistry of basalts drilled in the North Atlantic by IPOD Leg49: implications for mantle heterogeneity. Earth planet. Sci. Lett. 42, 77-97.

Zayed, A. M., (2006): Geology, petrography and geochemistry of Wadi Nefuz-Wadi Qusier area, SW Sinai, Egypt. M. Sc. Thesis (unpubl.), Cairo Univ., Giza, Egypt, 149p.

Zhu, L., Lui, J., Bagas, L., Carranza, E. M., Zhai, D., Meng, G., Wang, J., Wang, Y., Zhang, F. and Liu Z. (2019): The Yinachang $\mathrm{Fe}-\mathrm{Cu}-\mathrm{Au}-\mathrm{U}-\mathrm{REE}$ deposit and its relationship with intermediate to mafic intrusions, SW China: Implications for ore genesis and geodynamic setting. Ore Geol. Rev., 104, 190207. 
On the geochemistry of amphibolite enclaves

جيوكيمائية صخور الامفيبوليت المتواجدة بصخور النايس التابعة للحمي الافريقي ، وادي فيران - جنوب

غرب سيناء -مصر و علاقتها بصخور القوس النارية

$$
\text { نهلة احمد شلالي }
$$

قسم الجيولوجيا-كلية العوم- جامعة القاهرة

\section{الخلاصة}

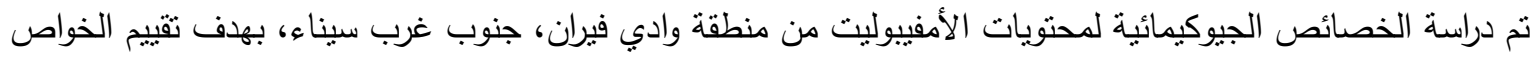
الصخرية الأصلية. تتواجد هذه المحنويات بداخل صخور النيس و الثنيست رسوبية الاصل،علي هيئة عدسات متفاوتة الاحبات

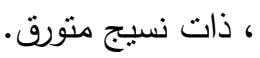

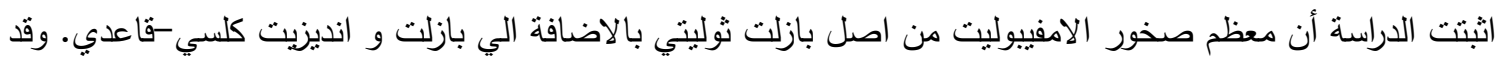

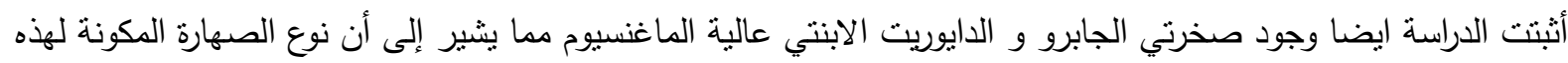

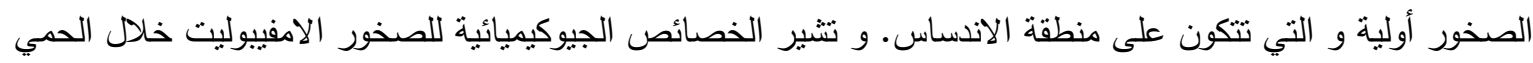
الافريقي ان هذه المنطقة ممنلة ببيئة خلف قوس القاري. 